УДК 332.1(338.2)

$10.17213 / 2075-2067-2021-3-135-148$

\title{
РЕЗУЛЬТАТИВНОСТЬ РЕГИОНАЛЬНОГО УПРАВЛЕНИЯ: СПОСОБЫ ИЗМЕРЕНИЯ
}

\section{(C) 2021 г. В. В. Глазунова}

\section{Институт экономики РАН, г. Москва, Россия}

Цель исследования. Для реализачии крупных федеральных и инфраструктурных проектов в регионах России потребуется оценка результативности региональных команд управления, что требует формирования методических подходов к измерению результативности управления.

Цель исследования сводится к апробаџии подхода по оченке результативности регионального управления.

Методологию составляют теория управления региональными экономиками, официальная методика оченки эффективности исполнительной власти регионов, утвержденная на федеральном уровне, а также предлагаемые альтернативные подходы. Тем самым исследование имеет сугубо прикладное назначение, сводимое к демонстрации положительных и отрицательных сторон реализачии альтернативных подходов к оценке результативности исполнительной власти субъектов РФ. В качестве рассматриваемого объекта выступают регионы Центрального федерального округа России. Именно по ним осуществляется апробация методики оценки эффективности исполнительной власти и ранжирование, исходя из условия равнозначности используемых показателей. Число применяемых показателей в два раза меньше, чем в официильной методике, причем они не предполагают добавочных усилий по проведению методических разработок, связанных с созданием учетного комплекса показателя или алгоритма его расчета. Это является значимым преимуществом относительно официильной методики, программирующей в виде необходимости именно такие действия в области учета и измерения.

Общий результат сводится к полученной сумме баллов, характеризующих в агрегированном виде действия команды управления, находящие свое выражение в изменении каждого из используемых показателей. Лучшему управлению за рассматриваемый период с 2016 по 2019 год соответствует большее число баллов, итоговая диаграмма отражает расположение регионов по результативности управления.

Ключевые слова: регион; Центральный федеральный округ; региональное управление; эффективность исполнительно власти региона; метод измерения результативности управления.

\section{REGIONAL GOVERNANCE PERFORMANCE: METHOD OF MEASUREMENT}

\section{(C) $2021 \quad$ V. V. Glazunova}

\section{Institute of Economics, Russian Academy of Sciences, Moscow, Russia}

The purpose of the study. Implementation of large federal and infrastructure projects in the regions of Russia will require an assessment of the performance of regional management 
teams, which requires the formation of methodological approaches to measuring management performance.

The purpose of the study is to test the approach to assessing the effectiveness of regional governance.

The methodology consists of the theory of management of regional economies, the official methodology for assessing the effectiveness of the executive power of the regions, approved at the federal level, as well as the proposed alternative approaches. Thus, the study has a purely applied purpose, reduced to demonstrating the positive and negative aspects of the implementation of alternative approaches to assessing the effectiveness of the executive power of the constituent entities of the Russian Federation. The considered object is the regions of the Central Federal District of Russia. It is on them that the methodology for assessing the effectiveness of the executive branch is tested and ranking, based on the condition of the equivalence of the indicators used. The number of indicators used is two times less than in the official methodology, and they do not imply additional efforts to carry out methodological developments associated with the creation of an accounting complex of an indicator or an algorithm for its calculation. This is a significant advantage in relation to the official methodology, which programs exactly such actions in the field of accounting and measurement as necessary.

The overall result is reduced to the received sum of points characterizing in an aggregated form the actions of the management team, which are expressed in the change in each of their used indicators. The best management for the period under review from 2016 to 2019 corresponds to a higher number of points, the final diagram reflects the location of the regions in terms of management effectiveness.

Key words: region; Central Federal District; regional administration; efficiency of the executive power of the region; method of measuring the effectiveness of management.

Введение. Российская экономика имеет большую специфику функционирования, вытекающую из различий пространственнорегионального построения $[4,8]$, особенностей федеративного устройства [1], что сказывается на развитии отраслей, неравномерно распределенных по различным регионам [3], формируя и бюджетные возможности развития [2], а также задает структуру экономического роста, имеющую помимо прочих и региональное измерение [5]. Обычно, рассматривая классические варианты региональной политики, обходят пространственные и федеративные особенности стороной $[8,11]$. Однако помимо этих аспектов из поля зрения исследователей часто выпадает, например, совокупность структурных особенностей и проблем развития конкретных регионов, отсутствие или наличие институтов регионального развития.

Нужно отметить, что общие вопросы влияния отдельных институтов на экономический рост исследованы весьма подробно
[10, 14-15]. Однако влияние вновь вводимых институтов развития, в частности регионов в разных странах и обстоятельствах, имеют неоднозначные результаты [6-7]. Так, агентства регионального развития, применявшиеся как институт развития регионов в Африке и Чешской республике, дают совсем не похожие результаты, которые нельзя назвать однозначно удовлетворительными [12-13], не говоря уже о том, чтобы переносить подобные институты в условия российских пространственных особенностей развития хозяйства. В работе 2012 года профессором О.С. Сухаревым подробно изложены аргументы, почему требуется исследовать имеющийся в регионах функционал, отвечающий за разработку и реализацию программы развития. Институциональные реорганизации могут негативно сказаться на управлении развитием, если не понять причин, почему не работают имеющиеся институты и те функции на уровне регионов, которые должны были исполняться [6]. Кроме этого, нужно учиты- 
вать институты саморазвития [7], возможное взаимодействие с ними предлагаемых новых институтов, ввод которых требует обоснования для каждого региона протяженной в пространстве экономики страны.

Однако, одновременно с институтами развития в России предлагаются институты оценки, в частности эффективности исполнительной власти регионов, то есть правила измерения эффективности регионального управления. Так, принят Указ Президента РФ от 4 февраля 2021 года №68, где утвержден список из 20 показателей оценки эффектив- ности региональной исполнительной власти с дальнейшей разработкой, совершенствованием методик измерения [9]. Отметим, что большая часть показателей не имеет напрямую отношения к оценке эффективности управления. В связи с этим возникает задача определить результативность регионального управления и апробировать иной подход к оценке успешности работы региональных команд управления, который предложен в трудах В.П. Чичканова и О.С. Сухарева ${ }^{1}$. Методологию исследования составляют базовые принципы управления и измерения

ВРП на душу населения в ценах 2015 года, руб. ${ }^{2}$

Таблица 1

\begin{tabular}{|c|l|c|c|c|c|c|}
\hline & & \multicolumn{5}{|c|}{ ВРП на душу населения региона, руб. } \\
\hline & & 2015 & 2016 & 2017 & 2018 & 2019 \\
\hline & РФ & $\mathbf{4 4 9 0 9 7 , 9}$ & $\mathbf{4 6 8 3 0 3 , 5}$ & $\mathbf{4 9 6 4 0 4 , 4}$ & $\mathbf{5 8 2 3 7 4 , 8}$ & $\mathbf{6 0 2 8 8 4 , 7}$ \\
\hline 1 & ЦФО & $\mathbf{5 8 0 7 0 6 , 6}$ & $\mathbf{6 0 8 5 8 1 , 5}$ & $\mathbf{6 4 4 5 9 6 , 2}$ & $\mathbf{7 4 6 3 7 0 , 0}$ & $\mathbf{7 7 3 0 1 1 , 8}$ \\
\hline 1.1 & Белгородская область & 447619,7 & 454469,6 & 472057,8 & 535584,2 & 550759,4 \\
\hline 1.2 & Брянская область & 221080,0 & 229157,1 & 239097,1 & 281013,5 & 299856,9 \\
\hline 1.3 & Владимирская область & 262945,5 & 280918,1 & 295414,7 & 344318,3 & 364957,3 \\
\hline 1.4 & Воронежская область & 345566,8 & 345263,9 & 357843,4 & 382364,6 & 398632,6 \\
\hline 1.5 & Ивановская область & 174687,5 & 180785,2 & 189096,4 & 237045,9 & 250608,9 \\
\hline 1.6 & Калужская область & 336353,9 & 358196,5 & 378494,1 & 450913,1 & 475570,3 \\
\hline 1.7 & Костромская область & 245940,9 & 251390,9 & 261842,7 & 302496,6 & 317759,6 \\
\hline 1.8 & Курская область & 301242,5 & 311016,2 & 324985,3 & 371468,3 & 400376,1 \\
\hline 1.9 & Липецкая область & 388074,7 & 411740,6 & 427453,6 & 502885,0 & 485573,1 \\
\hline 1.10 & Московская область & 437249,1 & 480976,4 & 484006,3 & 569544,9 & 584896,8 \\
\hline 1.11 & Орловская область & 273107,5 & 290486,0 & 296166,9 & 340270,2 & 359194,8 \\
\hline 1.12 & Рязанская область & 285257,8 & 298944,4 & 318896,9 & 369417,1 & 384248,6 \\
\hline 1.13 & Смоленская область & 266927,2 & 281928,7 & 304788,4 & 345113,4 & 361266,5 \\
\hline 1.14 & Тамбовская область & 300289,9 & 299510,1 & 299994,1 & 346392,6 & 361386,7 \\
\hline 1.15 & Тверская область & 251633,2 & 273821,9 & 292671,0 & 347725,4 & 367337,4 \\
\hline 1.16 & Тульская область & 316248,5 & 331524,6 & 344180,1 & 401772,2 & 413894,5 \\
\hline 1.17 & Ярославская область & 348375,7 & 367131,4 & 389304,7 & 432195,7 & 451135,5 \\
\hline 1.18 & г. Москва & 1102496,4 & 1140941,5 & 1224996,8 & 1410231,5 & 1451477,3 \\
\hline & & & & & \\
\hline
\end{tabular}

1 Эти работы оказались доступны автору на этапе рукописей, они создавали методику оценки эффективности исполнительной власти регионов, но без апробации. В этой статье проведены количественные расчёты, реализующие именно апробацию этих методик с некоторыми авторскими привнесениями.

2 Источник: Федеральная служба государственной статистики. Национальные счета [Электронный ресурс]. URL: https://rosstat.gov.ru/accounts. Данные приведены к постоянным ценам 2015 года через индекс физического объема ВРП. 
эффективности управления, а также сравнительный статистический анализ совместно с оценочным методом изменения отобранных показателей, характеризующих развитие регионов. Апробация альтернативной методики проводилась на примере регионов Центрального федерального округа. Общие результаты обобщены в разделе апробации методики и в заключении.

1. Результативность регионального управления. Под результативностью управ- ления понимается способность оказывать такие воздействия на управляемые объекты, которые изменяли бы состояние этих объектов в нужном направлении, то есть позволяли бы достичь целей управления. Эффективность управления можно рассматривать как близкий термин, но помимо достижения целей воздействия необходимо соизмерять силу и затраты, связанные с обеспечением тех или иных воздействий, расход ресурсов на достижение поставленных целей с приобретаемым доходом от достижения.

Таблица 2

Уровень бедности (доля населения с денежными доходами ниже прожиточного минимума)

\begin{tabular}{|c|l|c|c|c|c|c|}
\hline \multirow{2}{*}{} & \multirow{5}{*}{} & \multicolumn{5}{|c|}{ Уровень бедности } \\
& & \multicolumn{5}{|c|}{ ниже прожиточного минимума) } \\
\hline & & 2015 & 2016 & 2017 & 2018 & 2019 \\
\hline & РФ & $\mathbf{0 , 1 3 4}$ & $\mathbf{0 , 1 3 2}$ & $\mathbf{0 , 1 2 9}$ & $\mathbf{0 , 1 2 5}$ & $\mathbf{0 , 1 2 3}$ \\
\hline 1 & ЦФО & $\mathbf{0 , 1 0 3}$ & $\mathbf{0 , 1 0 0}$ & $\mathbf{0 , 0 9 5}$ & $\mathbf{0 , 0 9 0}$ & $\mathbf{0 , 0 9 0}$ \\
\hline 1.1 & Белгородская область & 0,085 & 0,081 & 0,078 & 0,075 & 0,078 \\
\hline 1.2 & Брянская область & 0,142 & 0,144 & 0,143 & 0,138 & 0,138 \\
\hline 1.3 & Владимирская область & 0,148 & 0,147 & 0,134 & 0,132 & 0,127 \\
\hline 1.4 & Воронежская область & 0,095 & 0,094 & 0,091 & 0,089 & 0,090 \\
\hline 1.5 & Ивановская область & 0,161 & 0,15 & 0,144 & 0,149 & 0,143 \\
\hline 1.6 & Калужская область & 0,108 & 0,102 & 0,100 & 0,104 & 0,102 \\
\hline 1.7 & Костромская область & 0,144 & 0,137 & 0,135 & 0,128 & 0,127 \\
\hline 1.8 & Курская область & 0,104 & 0,105 & 0,104 & 0,100 & 0,100 \\
\hline 1.9 & Липецкая область & 0,093 & 0,092 & 0,089 & 0,088 & 0,087 \\
\hline 1.10 & Московская область & 0,082 & 0,077 & 0,078 & 0,072 & 0,073 \\
\hline 1.11 & Орловская область & 0,146 & 0,143 & 0,140 & 0,136 & 0,138 \\
\hline 1.12 & Рязанская область & 0,130 & 0,128 & 0,133 & 0,130 & 0,128 \\
\hline 1.13 & Смоленская область & 0,177 & 0,179 & 0,170 & 0,166 & 0,164 \\
\hline 1.14 & Тамбовская область & 0,108 & 0,107 & 0,105 & 0,100 & 0,108 \\
\hline 1.15 & Тверская область & 0,131 & 0,128 & 0,126 & 0,123 & 0,118 \\
\hline 1.16 & Тульская область & 0,107 & 0,101 & 0,100 & 0,101 & 0,104 \\
\hline 1.17 & Ярославская область & 0,108 & 0,110 & 0,107 & 0,102 & 0,104 \\
\hline 1.18 & г. Москва & 0,088 & 0,085 & 0,074 & 0,067 & 0,066 \\
\hline & & & & & \\
\hline
\end{tabular}

3 Источник: Федеральная служба государственной статистики. Неравенство и бедность [Электронный pecypc]. URL: https://rosstat.gov.ru/folder/13723; Регионы России: Социально-экономические показатели 2020. Статистический сборник [Электронный ресурс]. Росстат. URL: https://rosstat.gov.ru/regional_statistics. Рacчет: численность населения с денежными доходами ниже величины прожиточного минимума, взятая из первого источника, разделена на общую численность населения на конец года по регионам, взятую из второго источника. 
Оценивая работу органов исполнительной власти в регионах, прежде всего, важна результативность, как они справляются с движением по установленным целям развития, причем как на региональном, так и на федеральном уровне. Предполагается, что эти цели формируются, исходя из реализации процедур в рамках действующей системы стратегического планирования, хотя именно для российских регионов это является проблемой проблем. Разумеется, цели различны, и их число весьма значительное, поэтому имеет смысл оценить общую результативность, сколько из них достигнуто за плановый период. К тому же исполнительская дисциплина важна с точки зрения оценки регионального бюджета. Другие показатели регионального развития могут характеризовать общие управленческие усилия власти. К ним относятся валовый региональный продукт на душу населения региона, величина реального дохода и заработной платы, уровень бедности и неравенства, объем загрязнений воздуха и воды, естественный прирост. Именно эти показатели использует альтернативная методика (отличается по числу и составу показателей - берется меньшее число параметров, включен показатель инновационной продукции и средней, а не ожидаемой продолжительности жизни населения региона).

Уровень неравенства (по коэффициенту фондов, охватывающему доходы региона) ${ }^{4}$

\begin{tabular}{|c|l|c|c|c|c|c|}
\hline \multirow{2}{*}{} & \multirow{5}{*}{} & \multicolumn{5}{|c|}{ Уровень неравенства (по коэффициенту фондов, } \\
\hline & & 2015 & 2016 & 2017 & 2018 & 2019 \\
\hline & РФ & $\mathbf{1 5 , 5}$ & $\mathbf{1 5 , 5}$ & $\mathbf{1 5 , 4}$ & $\mathbf{1 5 , 6}$ & $\mathbf{1 5 , 4}$ \\
\hline 1 & ЦФО & & & & & \\
\hline 1.1 & Белгородская область & 13,1 & 14 & 13,6 & 13,6 & 13 \\
\hline 1.2 & Брянская область & 11,8 & 12 & 11,8 & 12,1 & 11,9 \\
\hline 1.3 & Владимирская область & 10,4 & 10,1 & 10 & 9,6 & 9,3 \\
\hline 1.4 & Воронежская область & 15,1 & 14,8 & 14,2 & 14,1 & 13,7 \\
\hline 1.5 & Ивановская область & 10,4 & 10,9 & 11 & 10,6 & 10,8 \\
\hline 1.6 & Калужская область & 12 & 12,1 & 11,2 & 10,7 & 10,9 \\
\hline 1.7 & Костромская область & 10 & 10,3 & 10,2 & 9,2 & 9,2 \\
\hline 1.8 & Курская область & 12,2 & 12,2 & 11,7 & 11,5 & 11,3 \\
\hline 1.9 & Липецкая область & 12,8 & 12,9 & 12,9 & 13,4 & 13,3 \\
\hline 1.10 & Московская область & 13,6 & 14 & 13,6 & 13,6 & 13,5 \\
\hline 1.11 & Орловская область & 11 & 11,4 & 11,2 & 11,1 & 11 \\
\hline 1.12 & Рязанская область & 11,6 & 11,4 & 11,3 & 11,2 & 11,2 \\
\hline 1.13 & Смоленская область & 10,9 & 10,8 & 12,1 & 12,5 & 12,3 \\
\hline 1.14 & Тамбовская область & 12,4 & 12,6 & 12,3 & 12 & 11,4 \\
\hline 1.15 & Тверская область & 9,4 & 9,5 & 9,1 & 9,2 & 9,5 \\
\hline 1.16 & Тульская область & 10,9 & 11,1 & 10,9 & 10,2 & 9,8 \\
\hline 1.17 & Ярославская область & 12,6 & 12,3 & 11,5 & 10,5 & 10,5 \\
\hline 1.18 & г. Москва & 18,1 & 17,3 & 16,1 & 15,8 & 15,9 \\
\hline
\end{tabular}

4 Источник: ЕМИСС. Государственная статистика. Коэффициент фондов (соотношение денежных доходов $10 \%$ наиболее и 10\% наименее обеспеченного населения) [Электронный ресурc]. URL: https:/www.fedstat.ru/ indicator/31170. 
Согласно этой методике осуществим оценку результативности управления развитием регионов Центрального федерального округа России.

2. Измерение результативности регионального управления: альтернативная методика. Приведем результаты количественных оценок, входящих в методику девяти основных параметров (таблицы 1-9), и итоговую диаграмму ранжирования регионов Центрального федерального округа по выставленным баллам. Положительное изменение каждого показателя оценивается одним плюсом (рисунок 1), отрицательное изменение - минусом. Если показатель не изменяется (данный год к предыдущему), тогда оце- нивается, что происходило в экономике России. Если этот показатель улучшался для России, а в данном регионе не изменялся, то это минус, если в России ухудшался, а в регионе не изменялся - тогда плюс. Сумма плюсов и есть общий балл для региона. Если имеется информация за 2016-2019 годы и девять основных показателей, то максимальное число баллов равно 36. Условно можно выделить четыре группы регионов по девятибалловому диапазону. Первые девять баллов - это низкорезультативные с точки зрения управления регионы, вторые девять балов - это среднерезультативные (низкого уровня), третьи девять баллов - среднерезультативные высокого уровня и четвертые девять баллов высокорезультативные. Безусловно, такое

Коэффициент естественного прироста населения на 1000 чел. ${ }^{5}$

Таблица 4

\begin{tabular}{|c|l|c|c|c|c|c|}
\hline & & \multicolumn{5}{|c|}{ Коэффициент естественного прироста населения на 1000 чел. } \\
\hline & & 2015 & 2016 & 2017 & 2018 & 2019 \\
\hline & РФ & $\mathbf{0 , 3}$ & $\mathbf{- 0 , 0 1}$ & $-\mathbf{0 , 9}$ & $-\mathbf{1 , 6}$ & $\mathbf{- 2 , 2}$ \\
\hline 1 & ЦФО & $-\mathbf{1 , 8}$ & $-\mathbf{1 , 9}$ & $-\mathbf{2 , 5}$ & $-\mathbf{3}$ & $\mathbf{- 3 , 3}$ \\
\hline 1.1 & Белгородская область & $-2,4$ & $-2,8$ & $-3,8$ & $-4,3$ & $-4,8$ \\
\hline 1.2 & Брянская область & $-4,4$ & $-4,7$ & $-5,8$ & -6 & $-6,4$ \\
\hline 1.3 & Владимирская область & $-4,9$ & $-5,3$ & -6 & $-6,7$ & $-7,5$ \\
\hline 1.4 & Воронежская область & $-4,2$ & $-4,5$ & -5 & $-5,5$ & $-5,7$ \\
\hline 1.5 & Ивановская область & $-4,6$ & $-5,2$ & $-6,2$ & $-7,1$ & $-7,9$ \\
\hline 1.6 & Калужская область & $-2,4$ & $-2,9$ & -4 & $-4,7$ & $-5,7$ \\
\hline 1.7 & Костромская область & $-3,5$ & $-3,6$ & $-4,2$ & $-5,2$ & $-5,6$ \\
\hline 1.8 & Курская область & $-4,7$ & -5 & $-5,9$ & $-6,2$ & $-6,6$ \\
\hline 1.9 & Липецкая область & $-3,7$ & $-3,9$ & $-4,7$ & -5 & $-5,7$ \\
\hline 1.10 & Московская область & $-0,1$ & 0,1 & $-0,4$ & $-1,2$ & $-2,5$ \\
\hline 1.11 & Орловская область & $-5,2$ & $-5,5$ & $-6,3$ & $-6,8$ & $-7,2$ \\
\hline 1.12 & Рязанская область & $-4,7$ & $-4,7$ & $-5,5$ & $-6,2$ & $-6,9$ \\
\hline 1.13 & Смоленская область & $-5,8$ & $-5,9$ & $-6,4$ & $-7,2$ & $-7,6$ \\
\hline 1.14 & Тамбовская область & $-6,3$ & $-6,3$ & $-6,5$ & $-7,5$ & $-7,3$ \\
\hline 1.15 & Тверская область & $-6,5$ & $-6,6$ & -7 & $-7,7$ & $-7,9$ \\
\hline 1.16 & Тульская область & $-6,6$ & $-6,8$ & $-7,6$ & $-7,9$ & $-8,3$ \\
\hline 1.17 & Ярославская область & $-3,4$ & $-3,6$ & $-4,7$ & $-5,1$ & $-5,8$ \\
\hline 1.18 & г. Москва & 1,7 & 1,8 & 1,1 & 0,8 & 1,2 \\
\hline
\end{tabular}

5 Источник: Регионы России. Социально-экономические показатели 2020. Статистический сборник [Электронный ресурс]. Росстат. URL: https://rosstat.gov.ru/regional_statistics. 
выделение нормативное и условно, но, тем не менее, оно позволяет выделить некое ранжирование регионов и дать характеристику системе их управления. При отсутствии плюсов на данном интервале выставляют нулевой балл (согласно методике).

По исходным расчетным данным по регионам Центрального федерального округа России по девяти базовым параметрам (согласно методике требуется синхронное увеличение реальных располагаемых доходов и заработной платы, чтобы был выставлен плюс) в таблицах 1-9 далее осуществлялся анализ изменения каждого параметра для каждого региона. Если параметр улучшался в текущем году относительно предыдущего, то выставлялся плюс, затем считалось общее число плюсов, собранных регионом за период 2016-2019 гг. Эта сумма плюсов и составляет общий балл рейтинг региона с точки зрения того, как система управления обеспечивала развитие региональной экономики и решение социальных и экологических проблем.

В данном варианте методики не используется оценка исполнения региональной властью программных документов регионального и федерального уровня, так как эту статистику должны предоставлять регионы, и на сегодня сбор этих данных для отдельного исследователя затруднителен. Но этот показатель присутствует изначально в альтернативной методике и может использоваться

Ожидаемая продолжительность жизни при рождении, лет ${ }^{6}$

Таблица 5

\begin{tabular}{|c|l|c|c|c|c|c|}
\hline & & \multicolumn{5}{|c|}{ Ожидаемая продолжительность жизни при рождении, лет } \\
\hline & & 2015 & 2016 & 2017 & 2018 & 2019 \\
\hline & РФ & $\mathbf{7 1 , 3 9}$ & $\mathbf{7 1 , 8 7}$ & $\mathbf{7 2 , 7}$ & $\mathbf{7 2 , 9 1}$ & $\mathbf{7 3 , 3 4}$ \\
\hline 1 & ЦФО & $\mathbf{7 2 , 7 2}$ & $\mathbf{7 3 , 0 7}$ & $\mathbf{7 3 , 8 9}$ & $\mathbf{7 4 , 0 1}$ & $\mathbf{7 4 , 5 4}$ \\
\hline 1.1 & Белгородская область & 72,61 & 72,87 & 73,67 & 73,67 & 74,21 \\
\hline 1.2 & Брянская область & 70,36 & 70,92 & 71,27 & 71,71 & 72,31 \\
\hline 1.3 & Владимирская область & 69,82 & 70,28 & 71,15 & 71,23 & 71,87 \\
\hline 1.4 & Воронежская область & 71,67 & 72,08 & 73,03 & 73,15 & 73,63 \\
\hline 1.5 & Ивановская область & 70,62 & 70,77 & 71,47 & 71,29 & 71,84 \\
\hline 1.6 & Калужская область & 70,73 & 71,18 & 71,87 & 71,89 & 72,35 \\
\hline 1.7 & Костромская область & 70,38 & 70,87 & 71,81 & 71,87 & 72,35 \\
\hline 1.8 & Курская область & 70,8 & 70,94 & 71,74 & 71,91 & 72,27 \\
\hline 1.9 & Липецкая область & 71,07 & 71,62 & 72,46 & 72,62 & 73,34 \\
\hline 1.10 & Московская область & 72,26 & 72,5 & 73,34 & 73,52 & 73,86 \\
\hline 1.11 & Орловская область & 70,38 & 70,73 & 71,63 & 71,56 & 72,56 \\
\hline 1.12 & Рязанская область & 71,46 & 71,87 & 72,7 & 72,84 & 73,2 \\
\hline 1.13 & Смоленская область & 69,74 & 69,98 & 71,14 & 71,16 & 71,89 \\
\hline 1.14 & Тамбовская область & 71,67 & 72,11 & 73,21 & 72,95 & 73,56 \\
\hline 1.15 & Тверская область & 69,1 & 69,24 & 70,45 & 70,47 & 71,24 \\
\hline 1.16 & Тульская область & 70,06 & 70,56 & 71,18 & 71,77 & 72,21 \\
\hline 1.17 & Ярославская область & 70,98 & 71,21 & 71,85 & 72,25 & 72,92 \\
\hline 1.18 & г. Москва & 76,77 & 77,08 & 77,87 & 77,84 & 78,36 \\
\hline
\end{tabular}

6 Источник: Регионы России. Социально-экономические показатели 2020. Статистический сборник [Электронный ресурс]. Росстат. URL: https://rosstat.gov.ru/regional_statistics. 
в дальнейшем. Кроме этого, рост реальных расходов бюджета на одного жителя может отмечаться положительно лишь при ограничении на бюджетный дефицит. Планы ликвидации дефицитов региональных бюджетов и реструктуризации их задолженности разрабатываются Правительством России в 2021 года и на перспективу 2022-2023 гг. В связи с этим выставление плюса или минуса можно привязать к правилу преодоления проблемы дефицитного регионального бюджета. В этом случае рост реальных расходов означает увеличение финансирования социальных секторов региона. Чтобы не загромождать таблицами данную статью, набор набранных баллов каждым регионом по каждому показателю здесь опускается, но приводится диаграмма расположения регионов по общему набранному числу баллов (рисунок 1) как итог апробации рассматриваемой методики.

На рисунке 1 по убыванию числа баллов (слева направо) расположены регионы Центрального федерального округа России, что означает снижение результативности регионального управления. Можно выделить четыре участка по девять баллов каждый: от нуля до девяти баллов - низкорезультативные регионы (такие для Центрального округа отсутствуют), от девяти до восемнадцати бал-

Таблица 6

Реальные расходы регионального бюджета на одного жителя в ценах 2015 года, руб.7

\begin{tabular}{|c|l|c|c|c|c|c|}
\hline & & \multicolumn{5}{|c|}{ Реальные расходы регионального бюджета на одного жителя, руб. } \\
\hline & & 2015 & 2016 & 2017 & 2018 & 2019 \\
\hline 1 & ЦФО & $\mathbf{6 8 3 1 2 , 3 8}$ & $\mathbf{7 7 2 3 7 , 7 0}$ & $\mathbf{8 9 1 1 4 , 5 9}$ & $\mathbf{9 7 5 3 3 , 5 4}$ & $\mathbf{1 0 9 8 1 9 , 0 5}$ \\
\hline 1.1 & Белгородская область & 42916,91 & 43356,02 & 49626,38 & 56058,22 & 67491,68 \\
\hline 1.2 & Брянская область & 37018,60 & 42980,78 & 45919,71 & 48138,31 & 55841,08 \\
\hline 1.3 & Владимирская область & 32275,02 & 37770,19 & 40104,63 & 47029,40 & 52583,98 \\
\hline 1.4 & Воронежская область & 35657,09 & 40009,95 & 41798,65 & 48112,32 & 53909,34 \\
\hline 1.5 & Ивановская область & 32105,78 & 31822,73 & 32356,48 & 39196,14 & 45292,60 \\
\hline 1.6 & Калужская область & 47033,51 & 51032,27 & 58987,98 & 67347,38 & 72393,13 \\
\hline 1.7 & Костромская область & 34776,06 & 39319,17 & 40158,70 & 47515,19 & 56471,98 \\
\hline 1.8 & Курская область & 38592,90 & 43795,51 & 49200,60 & 53478,48 & 63051,84 \\
\hline 1.9 & Липецкая область & 42219,33 & 46372,08 & 47142,94 & 52139,79 & 59680,12 \\
\hline 1.10 & Московская область & 53661,47 & 54160,10 & 63045,75 & 69522,98 & 79657,27 \\
\hline 1.11 & Орловская область & 37922,81 & 41388,11 & 42582,69 & 46214,82 & 50318,76 \\
\hline 1.12 & Рязанская область & 37107,97 & 40139,58 & 43559,06 & 49251,69 & 57782,44 \\
\hline 1.13 & Смоленская область & 40728,96 & 43550,35 & 41924,41 & 44174,26 & 51124,35 \\
\hline 1.14 & Тамбовская область & 41808,25 & 45927,30 & 45041,90 & 48236,78 & 53544,33 \\
\hline 1.15 & Тверская область & 38186,20 & 38716,23 & 44485,24 & 45865,25 & 52053,13 \\
\hline 1.16 & Тульская область & 41022,76 & 44524,27 & 48498,93 & 51807,99 & 61105,68 \\
\hline 1.17 & Ярославская область & 44132,91 & 47492,08 & 52078,01 & 60773,91 & 63808,95 \\
\hline 1.18 & г. Москва & 123410,70 & 146581,02 & 172461,49 & 185589,77 & 205342,69 \\
\hline
\end{tabular}

7 Источники: а) Распоряжения правительства об утверждении отчетов об исполнении бюжетов регионов [Электронный pecypc]. URL: https://docs.cntd.ru/; б) Регионы России: Социально-экономические показатели 2020. Статистический сборник [Электронный ресурс]. Росстат. URL: https://rosstat.gov.ru/regional_statistics. Pacчет: Общие расходы бюджетов регионов за указанные годы были приведены к ценам 2015 года с использованием индекса «Реальные денежные доходы населения» (в \% к предыдущему году), приведенные к 2015 году расходы бюджетов на основе данных из источника (а) были разделены на численность населения на конец года (б). 
Изменение реальных денежных доходов населения и реальной начисленной заработной платы работников организаций (в \% к предыдущему году) ${ }^{8}$

\begin{tabular}{|c|c|c|c|c|c|c|}
\hline & & \multicolumn{5}{|c|}{$\begin{array}{l}\text { Реальные денежные доходы населения } \\
\text { (в \% к предыдущему году) }\end{array}$} \\
\hline & & 2015 & 2016 & 2017 & 2018 & 2019 \\
\hline & РФ & 96,4 & 95,5 & 99,8 & 101,1 & 101,7 \\
\hline 1 & ЦФО & 96,2 & 96,5 & 100,3 & 101 & 102,8 \\
\hline 1.1 & Белгородская область & 99,3 & 100,8 & 99,1 & 98,7 & 100,6 \\
\hline 1.2 & Брянская область & 97 & 95 & 99,4 & 102,1 & 100,5 \\
\hline 1.3 & Владимирская область & 99,5 & 92,2 & 100,9 & 96,4 & 101,9 \\
\hline 1.4 & Воронежская область & 101,1 & 93,6 & 97,4 & 100 & 101,1 \\
\hline 1.5 & Ивановская область & 95,5 & 98,5 & 100,4 & 94,4 & 99,5 \\
\hline 1.6 & Калужская область & 96,4 & 97,7 & 95,2 & 98 & 102,8 \\
\hline 1.7 & Костромская область & 98,6 & 98,1 & 99,8 & 94,7 & 100,9 \\
\hline 1.8 & Курская область & 100,4 & 93,2 & 99,1 & 100,1 & 100,9 \\
\hline 1.9 & Липецкая область & 96,1 & 96,8 & 100,1 & 100,1 & 102,6 \\
\hline 1.10 & Московская область & 97,5 & 99,7 & 100 & 102,6 & 102,1 \\
\hline 1.11 & Орловская область & 98,9 & 96 & 99,7 & 100,5 & 99,1 \\
\hline 1.12 & Рязанская область & 94,8 & 94,2 & 97,3 & 100,3 & 99,9 \\
\hline 1.13 & Смоленская область & 99,1 & 93,1 & 100,9 & 101 & 100,4 \\
\hline 1.14 & Тамбовская область & 98,5 & 95,8 & 97 & 98,8 & 98,1 \\
\hline 1.15 & Тверская область & 96,7 & 94,4 & 97,5 & 99,8 & 103,2 \\
\hline 1.16 & Тульская область & 99 & 97,9 & 97,7 & 95,9 & 99,9 \\
\hline 1.17 & Ярославская область & 99,5 & 93 & 98 & 96,2 & 99,5 \\
\hline \multirow[t]{4}{*}{1.18} & г. Москва & 94,4 & 95,7 & 101,5 & 101,8 & 104,3 \\
\hline & & \multicolumn{5}{|c|}{$\begin{array}{c}\text { Реальная начисленная заработная плата } \\
\text { работников организаций (в \% к предыдущему году) }\end{array}$} \\
\hline & & 2015 & 2016 & 2017 & 2018 & 2019 \\
\hline & РФ & 91 & 100,8 & 102,9 & 108,5 & 104,8 \\
\hline 1 & ЦФО & 90,3 & 101,7 & 101,6 & 108,8 & 106,2 \\
\hline 1.1 & Белгородская область & 93,2 & 100,8 & 104,5 & 106,8 & 104 \\
\hline 1.2 & Брянская область & 89 & 98,5 & 103,2 & 107 & 104 \\
\hline 1.3 & Владимирская область & 91 & 99,2 & 103,6 & 109,9 & 103,5 \\
\hline 1.4 & Воронежская область & 89,1 & 99,1 & 102,8 & 108,7 & 103,4 \\
\hline 1.5 & Ивановская область & 87,9 & 97,6 & 102,1 & 106 & 102,1 \\
\hline 1.6 & Калужская область & 90,3 & 98,3 & 103,4 & 107,8 & 103,9 \\
\hline 1.7 & Костромская область & 90,1 & 98,5 & 103,1 & 109,6 & 108,1 \\
\hline 1.8 & Курская область & 89,8 & 98,4 & 103,8 & 106 & 103,8 \\
\hline
\end{tabular}

8 Источник: Росстат. URL: https://rosstat.gov.ru/regional_statistics. 
Окончание таблицы 7

\begin{tabular}{|c|l|c|c|c|c|c|}
\hline 1.9 & Липецкая область & 92,1 & 100,4 & 105,1 & 107,8 & 103,3 \\
\hline 1.10 & Московская область & 91,1 & 96,3 & 105,7 & 106,5 & 102,2 \\
\hline 1.11 & Орловская область & 89,3 & 98,6 & 103,5 & 108,2 & 103,2 \\
\hline 1.12 & Рязанская область & 90 & 100,7 & 101,2 & 106,5 & 102,7 \\
\hline 1.13 & Смоленская область & 90,8 & 100,4 & 101,1 & 108,7 & 101,8 \\
\hline 1.14 & Тамбовская область & 90,9 & 97,9 & 102,9 & 106,7 & 101,9 \\
\hline 1.15 & Тверская область & 89,3 & 98,8 & 102,4 & 109,8 & 103,9 \\
\hline 1.16 & Тульская область & 91,3 & 99,7 & 104,1 & 106 & 105,7 \\
\hline 1.17 & Ярославская область & 89,8 & 98,7 & 104 & 106 & 101,6 \\
\hline 1.18 & г. Москва & 90,1 & 103 & 98,7 & 109,6 & 107,6 \\
\hline
\end{tabular}

Таблица 8

Сброс загрязненных сточных вод на человека, м 3 ччел. 9

\begin{tabular}{|c|l|c|c|c|c|c|}
\hline & & \multicolumn{4}{|c|}{ Сброс загрязненных сточных вод на человека, м $^{3}$ чел } \\
\hline & & 2015 & 2016 & 2017 & 2018 & 2019 \\
\hline & РФ & $\mathbf{9 8 , 3 9}$ & $\mathbf{1 0 0 , 2 6}$ & $\mathbf{9 2 , 5 2}$ & $\mathbf{8 9 , 4 9}$ & $\mathbf{8 5 , 8 7}$ \\
\hline 1 & ЦФО & $\mathbf{8 1 , 9 1}$ & $\mathbf{8 1 , 2 8}$ & $\mathbf{7 9 , 9 5}$ & $\mathbf{7 7 , 0 2}$ & $\mathbf{7 3 , 0 1}$ \\
\hline 1.1 & Белгородская область & 39,35 & 47,65 & 45,81 & 45,22 & 44,54 \\
\hline 1.2 & Брянская область & 47,31 & 47,5 & 45,42 & 45 & 42,75 \\
\hline 1.4 & Владимирская область & 78,02 & 78,42 & 76,2 & 72,47 & 69,22 \\
\hline 1.5 & Воронежская область & 50,15 & 52,25 & 51,01 & 51,12 & 51,2 \\
\hline 1.6 & Квановская область & 67,96 & 67,45 & 67,98 & 59,76 & 61,18 \\
\hline 1.7 & Костромская область & 55,3 & 55,56 & 54,43 & 53,38 & 55,29 \\
\hline 1.8 & Курская область & 9,82 & 10,69 & 11,66 & 10,84 & 9,96 \\
\hline 1.9 & Липецкая область & 65,74 & 71,8 & 66,96 & 60,31 & 66,73 \\
\hline 1.10 & Московская область & 147,29 & 143,74 & 138,08 & 125,81 & 113,12 \\
\hline 1.11 & Орловская область & 67,11 & 68,87 & 69,61 & 77,03 & 64,03 \\
\hline 1.12 & Рязанская область & 72,57 & 70,98 & 67,74 & 67,32 & 67,63 \\
\hline 1.13 & Смоленская область & 60,48 & 61,91 & 62,11 & 57,32 & 49,2 \\
\hline 1.14 & Тамбовская область & 39,05 & 39,42 & 43,56 & 44,29 & 42,7 \\
\hline 1.15 & Тверская область & 64,37 & 60,14 & 60,75 & 58,27 & 53,97 \\
\hline 1.16 & Тульская область & 108,9 & 107,4 & 107,24 & 105,48 & 105,05 \\
\hline 1.17 & Ярославская область & 158,02 & 140,83 & 140,6 & 138,1 & 134,77 \\
\hline 1.18 & г. Москва & 66,34 & 66,63 & 67,56 & 67,78 & 64,68 \\
\hline & & & & & 70,37 & 70,79 \\
\hline
\end{tabular}

9 Источник: Росстат. URL: https://rosstat.gov.ru/regional_statistics. Данные по сбросу загрязненных сточных вод в поверхностные водные объекты разделены на численность населения на конец года. 
Выбросы в атмосферу от стационарных источников на человека, кг/чел. ${ }^{10}$

Таблица 9

\begin{tabular}{|c|l|c|c|c|c|c|}
\hline & & \multicolumn{5}{|c|}{ Выбросы в атмосферу от стац.источников на человека, кг/чел } \\
\hline & & 2015 & 2016 & 2017 & 2018 & 2019 \\
\hline & РФ & $\mathbf{1 1 8 , 0 5}$ & $\mathbf{1 1 7 , 8 4}$ & $\mathbf{1 1 9 , 1 4}$ & $\mathbf{1 1 6 , 5}$ & $\mathbf{1 1 7 , 8 9}$ \\
\hline 1 & ЦФО & $\mathbf{3 9 , 1 5}$ & $\mathbf{3 9 , 7 6}$ & $\mathbf{3 9 , 3 3}$ & $\mathbf{3 8 , 8 3}$ & $\mathbf{4 0 , 6 5}$ \\
\hline 1.1 & Белгородская область & 76,13 & 72,76 & 75,48 & 113,05 & 101,36 \\
\hline 1.2 & Брянская область & 30,18 & 31,94 & 38,81 & 33,33 & 38,56 \\
\hline 1.4 & Владимирская область & 21,47 & 23,74 & 26,85 & 30,75 & 39,76 \\
\hline 1.5 & Иоронежская область & 29,58 & 31,26 & 32,58 & 44,67 & 45,18 \\
\hline 1.6 & Калужская область & 25,74 & 22,68 & 26,68 & 28,74 & 26,92 \\
\hline 1.7 & Костромская область & 70,66 & 77,16 & 83,98 & 50,24 & 69,51 \\
\hline 1.8 & Курская область & 27,68 & 34,73 & 35,87 & 46,07 & 52,54 \\
\hline 1.9 & Липецкая область & 283,74 & 276,82 & 283,48 & 276,22 & 272,17 \\
\hline 1.10 & Московская область & 30,2 & 34,08 & 30,25 & 29,35 & 24,57 \\
\hline 1.11 & Орловская область & 17,11 & 27,81 & 28,11 & 37,84 & 35,42 \\
\hline 1.12 & Рязанская область & 86,73 & 87,84 & 85,56 & 74,51 & 91,97 \\
\hline 1.13 & Смоленская область & 61,52 & 60,86 & 65,26 & 60,51 & 56,68 \\
\hline 1.14 & Тамбовская область & 53,33 & 53,85 & 60,99 & 55,12 & 72,49 \\
\hline 1.15 & Тверская область & 45,98 & 48,57 & 57,63 & 22,05 & 53,17 \\
\hline 1.16 & Тульская область & 98,94 & 94,73 & 80,43 & 73,7 & 72,99 \\
\hline 1.17 & Ярославская область & 71,54 & 67,66 & 60,03 & 57,94 & 73,37 \\
\hline 1.18 & г. Москва & 5,11 & 5,09 & 4,8 & 4,84 & 5,92 \\
\hline
\end{tabular}

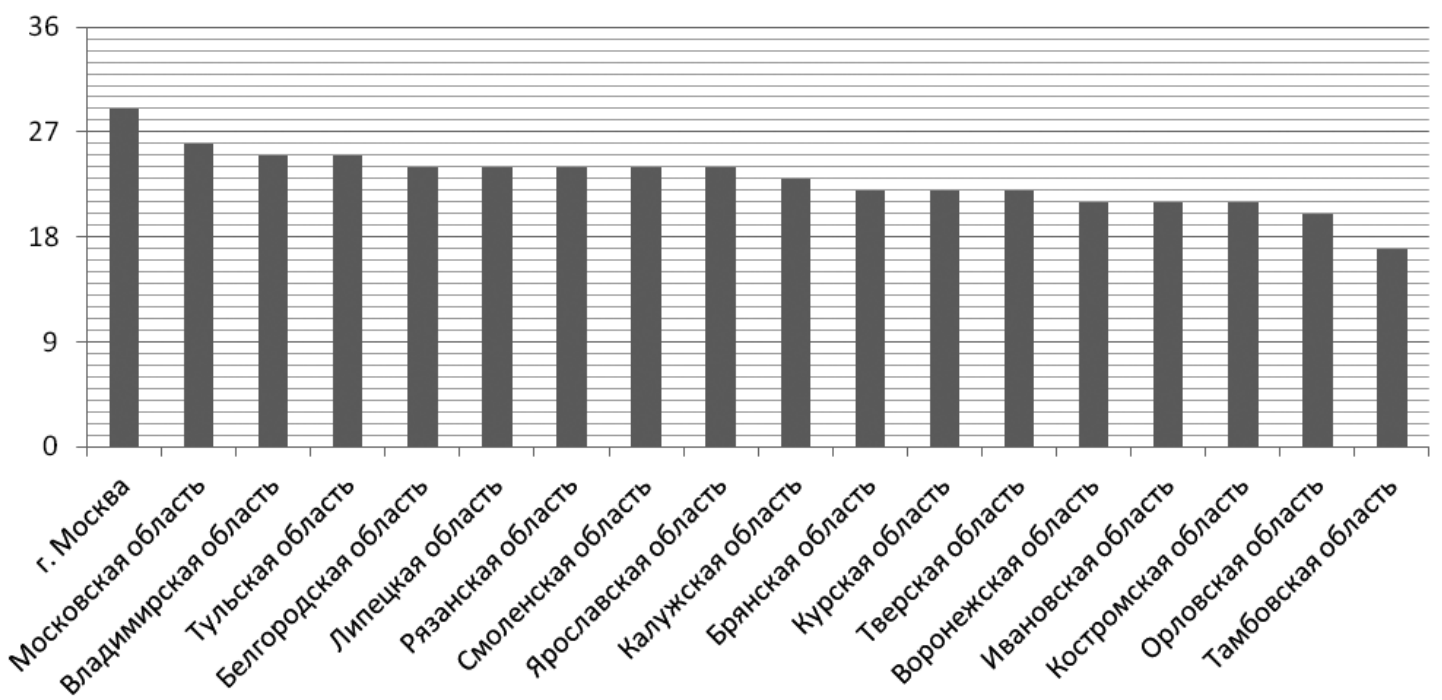

Рис. 1. Ранжирование регионов по числу набранных баллов (согласно назначенным баллам по таблицам 1-9)

10 Источник: Росстат. URL: https://rosstat.gov.ru/regional_statistics. Данные по выбросам загрязняющих веществ в атмосферный воздух, отходящих от стационарных источников, разделены на численность населения на конец года. 
лов - средней результативности, но низкого уровня (Тамбовская область), от восемнадцати до двадцати семи баллов - средней результативности, но высокого уровня (это большая часть регионов Центрального федерального округа от Московской до Орловской областей), и выше двадцати семи баллов до максимального значения в тридцать шесть баллов - это высокорезультативные регионы (город Москва).

Таким образом, апробация данной методики позволяет получить карту результативности общего регионального управления, которая дает характеристику не только тому, как реализуется региональная политика, но и как именно развивается сам регион. Любой подход в этом смысле будет условным, но преимущество имеет тот из них, который позволяет получить с малыми затратами весьма правдоподобную картину оценки эффективности исполнительной власти в регионах.

Заключение. Официальная методика оценки эффективности исполнительной власти в регионах России не позволяет получить аналогичную карту распределения эффективности регионального управления и развития.

Слишком большое число показателей, которые характеризуются низкой информативностью и уровнем согласования, а также измерительными и интерпретационными трудностями, делает применение стандартной методики не только условным, но и требующим относительно высоких затрат.

Как видно по полученным результатам, самая высокую результативность регионального управления для ЦФО показывает город Москва, затем блок регионов показывает отличающуюся, но среднюю результативность (высокого уровня), и только один регион Тамбовская область - показывает среднюю результативность низкого уровня. Тем самым исследование подтверждает существенный отрыв Москвы от регионов даже своего федерального округа по общим результатам развития и управления в 2016-2019 гг. на интервале, охваченном настоящим исследованием.

Представленная апробация альтернативного подхода, который также нельзя рассматривать как некую измерительную или оценочную панацею, вполне может использоваться в качестве более удобного спосо- ба решения поставленной задачи, сводимой к оценке региональных команд управления. Их деятельность выражается в изменении базовых показателей экономического, социального, экологического свойства, а также требует оценки административной дисциплины, сводимой к тому, как исполняются Указы Президента РФ, национальные проекты и программы развития федерального и регионального уровня. Альтернативная методика, применение которой продемонстрировано в настоящем исследовании, может быть легко вписана в процедуры стратегического планирования развития региональной экономики.

\section{Литература}

1. Валентей С.Д. Российский федерализм. Экономико-правовые проблемы. - М.: Алетейя, 2008. - 320 с.

2. Глазунова В.В. Оценка структурной эффективности бюджета брянской области на 2020 год и на плановый период 2021 и 2022 годов // Сборник статей III Всероссийской научно-практической конференции с международным участием «Экономическая политика и ресурсный потенциал региона». - 2020. - С. 45-49.

3. Леонтьев В.В. Межотраслевая экономика. - М.: Экономика, 1997. - 479 с.

4. Минакир П.А. Теоретические аспекты исследования пространственных экономических систем // Журнал экономической теории. - 2017. - №3. - С. 7-10.

5. Сухарев О.С. Структура экономического роста. Нужны ли кардинальные изменения. - М.: Ленанд, 2021. - 352 с.

6. Сухарев О.С. Институты регионального развития: концептуально-практический анализ организационных изменений // Экономический анализ: теория и практика. 2012. - №3. - C. 2-12.

7. Татаркин А.И. Институты саморазвития региональных социально-экономических систем // Институты современной экономики. - СПб: Алетейя, 2015. T. 4. - C. 87-160.

8. Татаркин А. И. Региональная направленность экономической политки Российской Федерации как института пространственного обустройства территорий // Экономика региона. — 2016. - №1. - С. 9-27. 
9. Указ Президента РФ от 4 февраля 2021 года №68 «Об оценке эффективности деятельности высших должностных лиц (руководителей высших исполнительных органов государственной власти) субъектов Российской Федерации и деятельности органов исполнительной власти субъектов Российской Федерации» [Электронный ресурс]. - Режим доступа: http://kremlin.ru/ acts/news/64970.

10. Ahmad M. Economic growth and convergence: Do institutional proximity and spillovers matter? // Journal of Policy Modeling. November-december 2017. — Vol. 39. - Issue 6. - P. 1065-1085.

11. Hoover E. M. An Introduction to Regional Economics. - Knopf, New York, 1971. $395 \mathrm{p}$.

12. Lawrence F. The Role of Local Economic Development Agencies in the South African Local Economic Development Landscape // Urban Forum, 2013. - Vol. 24. - Pp. 523-541.

13. Mcmaster I. Czech regional development agencies in a shifting institutional landscape // Europe-Asia Studies, 2006. — Vol.58. - Issue 3. - Pp. 347-370.

14. Neyapti B., Arasil Ya. The nexus of economic and institutional evolution Economic Modelling. - January 2016. — Vol. 52. Part B. - P. 574-582.

15. North D.C. Institutions and economic growth: An historical introduction. World Development. - September 1989. — Vol. 17. Issue 9. - P. 1319-1332.

\section{References}

1. Valentej S.D. Rossijskij federalizm. Jekonomiko-pravovye problemy [Russian federalism. Economic and legal problems]. - Moscow: Aletejja, 2008. - 320 p.

2. Glazunova $V . V$. Ocenka strukturnoj jeffektivnosti bjudzheta brjanskoj oblasti na 2020 god i na planovyj period 2021 i 2022 godov [Evaluation of the structural efficiency of the budget of the Bryansk region for 2020 and for the planning period of 2021 and 2022] // Sbornik statej III Vserossijskoj nauchno-prakticheskoj konferencii s mezhdunarodnym uchastiem «Jekonomicheskaja politika i resursnyj potencial regiona» [Collection of articles of the III All-Russian Scientific and practical Conference with in- ternational participation «Economic policy and resource potential of the region»]. - 2020. Pp. 45-49.

3. Leont'ev V.V. Mezhotraslevaja jekonomika [Mezhotraslevaya ekonomika]. - Moscow: Jekonomika, 1997. - $479 \mathrm{p}$.

4. Minakir P. A. Teoreticheskie aspekty issledovanija prostranstvennyh jekonomicheskih sistem [Theoretical aspects of the study of spatial economic systems] // Zhurnal jekonomicheskoj teorii [Journal of Economic Theory]. — 2017. №3. - Pp. 7-10.

5. Suharev O.S. Struktura jekonomicheskogo rosta. Nuzhny li kardinal'nye izmenenija [The structure of economic growth. Whether drastic changes are needed]. - Moscow: Lena$\mathrm{nd}, 2021 .-352 \mathrm{p}$.

6. Suharev O.S. Instituty regional'nogo razvitija: konceptual'no-prakticheskij analiz organizacionnyh izmenenij [Institutes of regional development: a conceptual and practical analysis of organizational changes] // Jekonomicheskij analiz: teorija i praktika [Economic analysis: theory and practice]. — 2012. — №3. - Pp. 2-12.

7. Tatarkin A.I. Instituty samorazvitija regional'nyh social'no-jekonomicheskih sistem [Institutes of self-development of regional socioeconomic systems] // Instituty sovremennoj jekonomiki [Institutes of Modern Economics]. Saint Petersburg: Aletejja, 2015. — Vol.4. Pp. 87-160.

8. Tatarkin A.I. Regional'naja napravlennost' jekonomicheskoj politki Rossijskoj Federacii kak instituta prostranstvennogo obustrojstva territorij [Regional orientation of the economic policy of the Russian Federation as an institution of spatial arrangement of territories]// Jekonomika regiona [The economy of the region]. - 2016. — №1. - Pp. 9-27.

9. Ukaz Prezidenta RF ot 4 fevralja 2021 goda №68 «Ob ocenke jeffektivnosti dejatel'nosti vysshih dolzhnostnyh lic (rukovoditelej vysshih ispolnitel'nyh organov gosudarstvennoj vlasti) subektov Rossijskoj Federacii i dejatel'nosti organov ispolnitel'noj vlasti subektov Rossijskoj Federacii» [Decree of the President of the Russian Federation №68 of February 4, 2021 «On Assessing the Effectiveness of the activities of Senior Officials (Heads of the Highest Executive bodies of State Power) of the Subjects of the Russian Federation and the activities of executive bodies of the subjects of the Russian Fed- 
eration»] [Jelektronnyj resurs]. — URL: http:// kremlin.ru/acts/news/64970.

10. Ahmad M. Economic growth and convergence: Do institutional proximity and spillovers matter? // Journal of Policy Modeling. November-december 2017. - Vol. 39. - Issue 6. - P. 1065-1085.

11. Hoover E. M. An Introduction to Regional Economics. - Knopf, New York, 1971. - 395 p.

12. Lawrence F. The Role of Local Economic Development Agencies in the South African Local Economic Development Landscape // Urban Forum, 2013. - Vol. 24. - Pp. 523-541.
13. Mcmaster I. Czech regional development agencies in a shifting institutional landscape // Europe-Asia Studies, 2006. — Vol. 58. - Issue 3. - Pp. 347-370.

14. Neyapti B., Arasil Ya. The nexus of economic and institutional evolution Economic Modelling. - January 2016. — Vol. 52. Part B. - P. 574-582.

15. North D.C. Institutions and economic growth: An historical introduction. World Development. - September 1989. - Vol. 17. Issue 9. - P. 1319-1332.

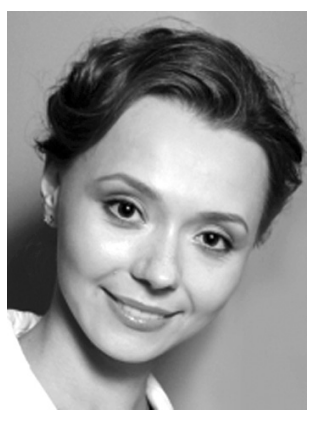

Глазунова Вильгельмина Витальевна - кандидат экономических наук, старший научный сотрудник Института экономики РАН. Область научных интересов: инновации, оценка инновационного потенциала организаций, управление промышленностью, структурный анализ экономических систем, экономическая синергетика, устойчивость экономической динамики.

Glazunova Vilhelmina Vitalievna - Candidate of Economic Sciences, Senior Researcher, Institute of Economics, Russian Academy of Sciences. Research interests: innovations, assessment of innovative potential of organizations, industrial management, structural analysis of economic systems, economic synergy, stability of economic dynamics.

117218, г. Москва, Нахимовский пр., 32

32 Nakhimovsky av., 117218, Moscow, Russia

E-mail: o_sukharev@list.ru 